\title{
Genome-wide association study identifies novel type II diabetes risk loci in Jordan subpopulations
}

\author{
Rana Dajani ${ }^{\text {Corresp., }}{ }^{1}$, Jin Li ${ }^{2,3}{ }^{\text {， Zhi Wei }}{ }^{4}$, Michael E March ${ }^{2}$, Qianghua Xia ${ }^{3,5}$, Yousef Khader ${ }^{6}$, Nancy \\ Hakooz $^{7}$, Raja Fatahallah ${ }^{8}$, Mohammed El-Khateeb ${ }^{8}$, Ala Arafat ${ }^{8}$, Tareq Saleh ${ }^{1}$, Abdel R Dajani ${ }^{1}$, Zaid Al- \\ Abbadi ${ }^{1}$, Mohamed Abdul Qader ${ }^{1}$, Abdel H Shiyab ${ }^{9}$, Anwar Bateiha ${ }^{6}$, Kamel Ajlouni $^{8}$, Hakon Hakonarson \\ Corresp. 2, 5, 10 \\ 1 Department of Biology and Biotechnology, Hashemite University, Zarqa, Jordan \\ 2 Center for Applied Genomics, The Children's Hospital of Philadelphia, Philadelphia, Pennsylvania, United States \\ 3 Department of Cell Biology, Tianjin Medical University, Tianjin, China \\ 4 Department of Computer Science, New Jersey Institute of Technology, Newark, New Jersey, United States \\ 5 Divisions of Human Genetics, The Children's Hospital of Philadelphia, Philadelphia, Pennsylvania, United States \\ 6 Department of Community Medicine, Public Health and Family Medicine, Faculty of Medicine, Jordan University for Science and Technology, Irbid, Jordan \\ 7 Department of Biopharmaceutics and Clinical Pharmacy Faculty of Pharmacy, University of Jordan, Amman, Jordan \\ 8 National Center for Diabetes, Endocrinology and Genetics, Amman, Jordan \\ 9 Department of Anthropology, Yarmouk University, Irbid, Jordan \\ 10 The Perelman School of Medicine, University of Pennsylvania, Philadelphia, PA, United States \\ Corresponding Authors: Rana Dajani, Hakon Hakonarson \\ Email address: rdajani@hu.edu.jo, hakonarson@email.chop.edu
}

The prevalence of Type II Diabetes (T2D) has been increasing and has become a disease of significant public health burden in Jordan. None of the previous genome-wide association studies (GWAS) have specifically investigated the Middle-East populations. The Circassian and Chechen communities in Jordan represent unique populations that are genetically distinct from the Arab population and other populations in the Caucasus. Prevalence of T2D is very high in both the Circassian and Chechen communities in Jordan despite low obesity prevalence. We conducted GWAS on T2D in these two populations and further performed meta-analysis of the results. We identified a novel T2D locus at chr20p12.2 at genome-wide significance ( $\mathrm{rs6134031}, \mathrm{P}=1.12 \times 10^{-8}$ ) and we replicated the results in the Wellcome Trust Case Control Consortium (WTCCC) dataset. Another locus at chr12q24.31 is associated with T2D at suggestive significance level (top SNP rs4758690, $\mathrm{P}=4.20 \times 10^{-5}$ ) and it is a robust eQTL for the gene, $\operatorname{MLXIP}\left(P=1.10 \times 10^{-14}\right)$, and is significantly associated with methylation level in MLXIP, the functions of which involves cellular glucose response. Therefore, in this first GWAS of T2D in Jordan subpopulations, we identified novel and unique susceptibility loci which may help inform the genetic underpinnings of T2D in other populations. 
1 Genome-Wide Association Study Identifies Novel Type II Diabetes Risk Loci in Jordan

2

3

4 Rana Dajani ${ }^{1 *}$, Jin $\mathrm{Li}^{2,3^{*}}$, Zhi Wei ${ }^{4}$, Michael E. March ${ }^{2}$, Qianghua Xia ${ }^{5,3}$, Yousef Khader ${ }^{6}$, Nancy

5 Hakooz $^{7}$, Raja Fatahallah ${ }^{8}$, Mohammad El-Khateeb ${ }^{8}$, Ala Arafat ${ }^{8}$, Tarek Saleh ${ }^{1}$, Abdel Rahman

6 Dajani $^{1}$, Zaid Al-Abbadi ${ }^{1}$, Mohamed Abdul Qader ${ }^{1}$, Abdel Haleem Shiyab ${ }^{9}$, Anwar Bateiha $^{6}$,

7 Kamel Ajlouni ${ }^{8}$, Hakon Hakonarson ${ }^{2,5,10}$

8

$9{ }^{1}$ Department of Biology and Biotechnology, Hashemite University, Zarqa, Jordan

$10{ }^{2}$ Center for Applied Genomics, The Children's Hospital of Philadelphia, Philadelphia,

11 Pennsylvania 19104, USA

$12{ }^{3}$ Department of Cell Biology, Tianjin Medical University, Tianjin, China

$13{ }^{4}$ Department of Computer Science, New Jersey Institute of Technology, New Jersey, USA

$14{ }^{5}$ Divisions of Human Genetics, The Children's Hospital of Philadelphia, Philadelphia,

15 Pennsylvania 19104, USA

$16{ }^{6}$ Department of Community Medicine, Public Health and Family Medicine, Faculty of

17 Medicine, Jordan University for Science and Technology, Irbid, Jordan

${ }^{7}$ Department of Biopharmaceutics and Clinical Pharmacy Faculty of Pharmacy-University of

Jordan, Amman, Jordan

${ }^{8}$ National Center for Diabetes, Endocrinology and Genetics, Amman, Jordan

${ }^{9}$ Department of Anthropology, Yarmouk University, Irbid, Jordan

23 19104, USA.

24

$25 * \mathrm{RD}$ and JL contributed equally to this work. 
27 Correspondence should be addressed to

28 Dr. Hakon Hakonarson

29 The Children's Hospital of Philadelphia and University of Pennsylvania

$3034^{\text {th }}$ street and Civic Center Blvd., Philadelphia, PA, 19104

31 Email: hakonarson@email.chop.edu

32 267-426-0088 (phone); 267-426-0363 (fax)

33 and

34 Rana Dajani

35 Associate Professor Molecular Cell Biology

36 Biology Department

37 Hashemite University

38 P. O. Box 150459

39 Zarqa 13115 Jordan

40 Tel : +962(5) 3903333

41 Fax : +962 (5) 3826613

42 email : rdajani@hu.edu.jo

43 Cell phone: 00962798859335

44

45

46

47

48

49

50

51

52 


\section{Abstract}

57 The prevalence of Type II Diabetes (T2D) has been increasing and has become a disease of 58 significant public health burden in Jordan. The genetic determinants of T2D in Middle-East 59 populations have not been well studied by genome-wide association studies (GWAS). The

60 Circassian and Chechen communities in Jordan represent unique populations that are genetically

61 distinct from the Arab population and other populations in the Caucasus. Prevalence of T2D is

62 very high in both the Circassian and Chechen communities in Jordan despite low obesity

63 prevalence. We conducted GWAS on T2D in these two populations and further performed meta-

64 analysis of the results. We identified a novel T2D locus at chr20p12.2 at genome-wide

65 significance $\left(\mathrm{rs} 6134031, \mathrm{P}=1.12 \times 10^{-8}\right)$ and we replicated the results in the Wellcome Trust Case

66 Control Consortium (WTCCC) dataset. Another locus at chr12q24.31 is associated with T2D at a

67 suggestive significance level (top SNP rs4758690, $\mathrm{P}=4.20 \times 10^{-5}$ ). This SNP is a robust eQTL for

68 the gene, $\operatorname{MLXIP}\left(\mathrm{P}=1.10 \times 10^{-14}\right)$, and is significantly associated with methylation level in

$69 M L X I P$, the functions of which involves cellular glucose response. Therefore, in this first GWAS

70 of T2D in Jordan subpopulations, we identified novel and unique susceptibility loci which may

71 help inform the genetic underpinnings of T2D in other populations. 


\section{Introduction}

76 Diabetes is among the most common non-communicable diseases globally. It has been estimated

77 that there are currently about 194 million people at the age of 20 to 79 with diabetes worldwide

78 and that this number will further increase to 333 million by 2025 (Wild et al. 2004). Diabetes is

79 the fifth main cause of death in Jordan, afflicting 16 percent of Jordanian adult citizens; another

8023.8 percent of adults in Jordan are also on the brink of becoming diabetics according to a study

81 from 2007 by the Heart and Capillary Disease Prevention directorate (HCDP) of the Ministry of

82 Health in Jordan; and the rate of diabetes prevalence in Jordan is 30.5 percent among both

83 children and adults (Ajlouni et al. 2008). Thus diabetes presents a significant public health

84 burden to the Jordan community. Type II Diabetes (T2D) is the major type of diabetes, which

85 accounts for $95 \%$ percent of all diabetes cases worldwide.

86

87 Despite extensive research efforts for more than a decade and some notable successes, much of

88 the genetic basis of common human diseases remains unresolved (Hirschhorn \& Daly 2005). The

89 genome-wide association study (GWAS) has been a powerful approach for identifying novel

90 susceptibility loci for complex diseases (Barrett \& Cardon 2006; Pe'er et al. 2006), such as T2D.

91 To date, more than 80 T2D susceptibility loci have been uncovered by GWAS. However, the

92 heritability attributed to these loci remains as low as just 10\% (Imamura et al. 2016). In addition, 
93 these studies have mostly focused on populations of European ancestry and East Asians, with a

94 few studies on South Asians and Mexicans. The genetic determinants of T2D in Middle-East

95 populations have not been extensively studied by GWAS and limited evidence suggested that at

96 least some of the reported T2D loci showed differential associations in different populations in

97 the Middle East (Mtiraoui et al. 2012). It has also been reported that the presentation of T2D is

98 different between Middle-East immigrants and European patients (Glans et al. 2008), implying

99 some different genetic basis between populations. Given the prevalence of the disease in the

100 region, more research is warranted to understand the genetic basis of T2D specific to given

101 Middle Eastern populations.

102

103 The Circassians and the Chechens are two ethnic populations of ancient descent in Jordan, both

104 of which are the largest indigenous nationalities of the North Caucasus (Barbujani et al. 1994a;

105 Bulayeva 2006; Nasidze et al. 2001). These two populations are descendants of a single ancient

106 origin with later divisions along linguistic and geographic borders (Nasidze et al. 2004; Nasidze

107 et al. 2001). After immigrating to Jordan 140 years ago, Circassians and Chechens in Jordan are

108 endogamous and have managed to keep their separate sense of identity and ethnicity during the

109 last one hundred years in Jordan (Kailani 2002). Previous analysis of classical genetic markers

110 such as blood groups and serum proteins have also shown statistical significant genetic diversity

111 in the Caucasus (Barbujani et al. 1994a; Barbujani et al. 1994b), which has been further

112 confirmed by mitochondrial DNA and Y chromosome analysis (Nasidze et al. 2004; Nasidze et 
113 al. 2001). While a T2D GWAS has been conducted in the Lebanese population (Ghassibe-

114 Sabbagh et al. 2014), the Lebanese are Arab in origin; Circassians and Chechans are a separate,

115 non-Arab ethnic group. These are clearly different populations, with different ancestries. The

116 Circassian and Chechen communities may provide us an opportunity to study a genetically

117 unique population and compare genetic basis for complex human diseases between different

118 populations.

119

120 T2D has become an alarming public health issue in Jordan. Epidemiology studies showed that

121 the prevalence of impaired fasting glycemia is $18.5 \%$ and $14.6 \%$ and prevalence of diabetes is

$1229.6 \%$ and $10.1 \%$ for Circassians and Chechens respectively(Dajani et al. 2012). In view of the

123 very high incidence of T2D in Jordan and the genetic distinctness of Circassian and Chechan

124 populations, we performed a GWAS to search for genetic factors contributing to T2D in these

125 two populations and compared the results with European population.

126

127 Materials \& Methods

128 Ethics Statement

129 The study has been approved by the institutional review board committee at the

130 National Center for Diabetes, Endocrinology and Genetics of Jordan (approval number:

131 457/9.MS). The written informed consent was given by all participants. 


\section{Study subjects and sample collection}

134 A random sample of $\mathrm{N}=144$ from the Chechen population in Jordan and a random sample of $\mathrm{N}$

$135=140$ from the Circassian population in Jordan were recruited to participate in the study. Each

136 participant in the study filled out a survey that included pedigree information. The identities of

137 parents, grandparents, and great-grandparents (both maternally and paternally) were reported in

138 the survey and any individual with non-Chechen heritage for even one person in his/her pedigree

139 was excluded for the Chechen subpopulation; the same identity confirmation was conducted for

140 the Circassian subpopulation.

141 A subject was defined as affected by diabetes mellitus if this diagnosis is known to the patient or,

142 according to the ADA definitions, if fasting serum glucose is $7 \mathrm{mmol} / \mathrm{L}(126 \mathrm{mg} / \mathrm{dl})$ or more.

143 Impaired fasting glucose was defined as a fasting serum glucose level of $\geq 6.1 \mathrm{mmol} / \mathrm{L}$ (100

$144 \mathrm{mg} / \mathrm{dl}$ ) but $<7 \mathrm{mmol} / \mathrm{L}$. The glycemic control was assessed using $\mathrm{HbA}_{1 \mathrm{c}}$. Patients with previously

145 diagnosed diabetes who had $\mathrm{HbA}_{1 \mathrm{c}}>7 \%$ were defined as having 'unsatisfactory' glycemic

146 control.

148 Sample collection

149 Nine $\mathrm{ml}$ of whole blood was drawn in EDTA tubes from the subjects by vacutainer system.

150 Genomic DNA was isolated from whole blood sample using the phenol-chloroform protocol.

151

152 Genotyping and quality control 
153 We performed high-throughput, genome-wide SNP genotyping, using the InfiniumII OMNI-

154 Express BeadChip technology (Illumina), at the Center for Applied Genomics (CAG) at the

155 Children's Hospital of Philadelphia (CHOP), USA. Sample quality control (QC) was performed

156 based on the following measures: sample call rate, overall heterozygosity, relatedness testing and

157 other metrics. Samples were excluded from analysis for SNP call rate $<95 \%$, heterozygosity

158 beyond five standard deviation of the mean. One sample from each pair of duplicated or cryptic

159 related samples was removed. For each pair of duplicate or related samples the sample with the

160 highest SNP call rate was kept in the dataset. In the SNP-based QC, SNPs with a call rate $<95 \%$,

161 minor allele frequency $<1 \%$ or showing significant deviation from Hardy-Weinberg-Equilibrium

162 (HWE test P-value $<10^{-4}$ ) in the controls were removed. All QC steps were carried out using the

163 software package PLINK (Purcell et al. 2007)

164

165 Principal component analysis (PCA)

166 PCA was conducted to confirm ethnic identity and to generate covariates to control for

167 population stratification in the association analysis. LD-pruning was performed using PLINK,

168 and only independent $\left(\mathrm{r}^{2}<0.2\right)$, autosomal non-GC/AT SNPs were included in the PCA, which

169 was conducted using EIGENSTRAT (Price et al. 2006) version 3.0.

170

171 Association analysis and meta-analysis 
172 The single-marker analysis for the genome-wide data was carried out using logistic regression on

173 allele counts with the first 10 principle components as covariates. P values and odds ratios with

174 the corresponding $95 \%$ confidence intervals were calculated for the association analysis in

175 Chechen and Circassian subpopulations separately. Both association and meta-analysis were

176 performed using PLINK.

177

178 The WTCCC cohort

179 The cohort of European population was from WTCCC, which has been reported before

180 (Wellcome Trust Case Control 2007). All the samples were genotyped on Affymetrix Genome-

181 Wide Human SNP Array 5.0. We similarly performed sample and SNP based QC steps and

182 excluded non-European subjects based on PCA. Logistic regression was performed including the

183 first three principal components as covariates.

184

185 Imputation analysis

186 The regional imputation at the locus of chr12q24.31 was conducted in two steps. First, the

187 genotype data were prephased with SHAPEIT (Delaneau et al. 2012; Delaneau et al. 2013)

188 version 2, and then genotype imputation was performed using IMPUTE 2 (Howie et al. 2009;

189 Marchini et al. 2007) with the 1000 Genome Phase 3

190 (https://mathgen.stats.ox.ac.uk/impute/1000GP\%20Phase\%203\%20haplotypes\%206\%20October

$191 \% 202014 . h t m l)$ as the reference panel. Missing data likelihood score test was conducted to 
192 assess the association of each imputed SNP genotype with T2D using software SNPTEST

193 (Marchini et al. 2007) V2, including the first three principal components as covariates. SNPs

194 with info score $<0.8$ or with HWE-test $\mathrm{p}$-value $<1 \times 10^{-06}$ were excluded from association testing.

195

196 Analysis of methylation data

197 Genomic DNA of a subset of samples in the biorepository of CAG was isolated from peripheral

198 blood mononuclear cells. Genome-wide methylation profiling was conducted on the Infinium

199 HumanMethylation450 BeadChip Kit at CAG according to the manufacturers' protocols.

200 Methylation data were exported from the Illumina GenomeStudio and loaded into the R

201 statistical package (r-project.org) using the lumi package (Du et al. 2010; Lin et al. 2008). After

202 adjusting for quantile color balance and background level and simple scaling normalization, M-

203 value density and CpG-site intensity were plotted and aberrant chips were removed. These

204 samples have also been genotyped at CAG and their genetic ethnicity was checked by PCA. We

205 extracted the M-values (the $\log 2$ ratio between the methylated and unmethylated probe

206 intensities) and the genotype information of the 425 subjects of European ancestry. We removed

207 subjects of missing genotype at SNP rs4785690 and extreme outlier values of methylation M-

208 values ( $\geq$ median M-value of the genotype group $\pm 3 \mathrm{SD})$ and then assessed the association between

209 the additive genotype at rs4785690 and methylation M-value in gene MLXIP using linear

210 regression including sex, age, and 10 genotype-derived principle components. Box-plots were

211 generated using R package. 


\section{Results}

214 Identification of novel T2D signals in Jordan subpopulations. To understand the genetic basis

215 for T2D in Jordan populations, we conducted GWAS in Chechen and Circassian subpopulations

216 of Jordan. The sample information after QC is summarized in Table 1. Specifically, for the

217 Chechen subpopulation, we have 34 cases and 109 controls; for the Circassian subpopulation, we

218 have 33 cases and 105 controls (Table 1). Approximately 645,000 SNPs in each subpopulation

219 passed QC. We conducted logistic regression analyses separately in each population, including

220 ten genotype-derived principal components as covariates. There was no signal that reached

221 genome-wide significance, however there are several SNPs at suggestive level of significance (P

$222<1 \times 10^{-4}$ ) in each subpopulation (Supplementary Tables 1-2). Then we performed meta-analysis

223 of the association results from the two subpopulations. In the meta-analysis, we observed a signal

224 at genome-wide significant level (SNP rs6134031, P-value $\left.=1.12 \times 10^{-8}\right)$ under both fixed effect

225 model and random effect model (Supplementary Fig. 1, Fig. 1, Table 2). This SNP is located at

226 the 5' of the $J A G 1$ gene (Fig. 1). In addition, there is another signal with multiple SNPs showing

227 suggestive evidence of association ( $\mathrm{P}$-value $<1 \times 10^{-4}$ ), with SNP rs4758690 having the lowest P-

228 value at $4.20 \times 10^{-5}$ (Supplementary Fig. 1, Table 2, Fig. 1). SNP rs4758690 is located in the intron

229 of $M L X I P$, a gene involved in transcriptional regulation of genes in glucose metabolism. Taken

230 together, these results demonstrate significant GWAS associations to novel T2D susceptibility

231 loci in Jordan subpopulations. 
233 Test the association signals in European population. We then investigated whether these

234 association signals exist in populations of other ethnicities. We examined the association of these

235 SNPs in the T2D dataset of the Wellcome Trust Case Control Consortium (WTCCC)(Wellcome

236 Trust Case Control 2007) which is composed of 1999 cases and 3004 controls, genotyped on the

237 Affymetrix Genome-Wide Human SNP Array 5.0. After QC, 1952 cases and 2960 controls of

238 European ancestry remained for association analysis by logistic regression. The top SNP in the

239 Jordan analysis, rs6134031 demonstrated nominally significant association with T2D in the

240 WTCCC cohort $(\mathrm{P}=0.012)$ and the same direction of effect (Table 2). The SNP rs4758690 is not

241 genotyped on the Affymetrix GW5.0 Array, so we conducted imputation over this region in the

242 replication cohort. Based on the imputed genotype data, we did not observe a significant

243 association to $\mathrm{rs} 4758690(\mathrm{OR}=1.01, \mathrm{P}=0.61)$.

245 Correlation of T2D variants with $M L X I P$ gene expression and methylation. Interrogating

246 these T2D variants in the GTEx dataset (GTEx Consortium 2015), we uncovered a nominally

247 significant association between SNP rs6134031 and $J A G 1$ expression, in Esophagus -

248 Muscularis (Beta=-0.15, $\mathrm{P}=0.0073$, Supplementary Fig. 2) and a marginal correlation in

249 pancreatic tissue which is of potential biological relevance to T2D (Beta=-0.13, $\mathrm{P}=0.071$,

250 Supplementary Fig. 2). Though it is not significant, we did observe a trend of association

251 between the doses of minor allele $\mathrm{T}$ and a lower expression of $J A G 1$. 
252 On the other hand, we found a genome-wide significant eQTL effect of SNP rs4758690 for gene

$253 M L X I P$ expression in transverse colon $\left(\mathrm{Beta}=0.46, \mathrm{P}=1.10 \times 10^{-14}\right)$ and small intestine terminal

254 ileum $\left(B e t a=0.42, P=4.20 \times 10^{-7}\right)$ tissue specimens (Fig. 2). A similar significant eQTL effect was

255 reported for $M L X I P$ expression in normal pre-pouch ileum in another study examining eQTLs in

256 human intestine tissues (Kabakchiev \& Silverberg 2013).

257 Further, we found that SNP rs4758690 is significantly associated with the methylation probe

$258 \operatorname{cg} 22729539\left(\mathrm{P}=3.07 \times 10^{-5}\right)$ residing within an intron of the longest isoform of MLXIP (Fig. 3).

259 This site is absent in other short isoforms. We observed a positive correlation between the eQTL

260 and the methylation data at this locus. As methylation is one of the important mechanisms

261 regulating gene expression, these results are of potential interest. The minor allele $\mathrm{G}$ confers a

262 lower expression of $M L X I P$ compared to the major allele A, as well as a reduced methylation

263 level at probe $\operatorname{cg} 22729539$, consistent with previous reports that gene body methylation was

264 found to be positively correlated with gene expression (Yang et al. 2014). In addition,

$265 \operatorname{cg} 22729539$ resides in a region with multiple histone modifications and transcription factor

266 binding in pancreatic islets and liver cells which are central to T2D (Supplementary Fig. 3) and

267 additional T2D relevant cell lines (Supplementary Table 3) (Bhandare et al. 2010; Encode

268 Project Consortium 2012; Parker et al. 2013; Pasquali et al. 2014; Roadmap Epigenomics et al.

269 2015). The bound transcription factors include CEBPB which is known to function in

270 adipogenesis (Darlington et al. 1998), ER stress and pancreatic $\beta$ cell failure (Matsuda et al. 
271 2010) (Supplementary Table 3), therefore this region may function as active cis-regulatory

272 element, regulating MLXIP expression.

273

274 The expression of $\boldsymbol{J A G} 1$ and $\boldsymbol{M L X I P}$. The biological relevance of these two genes to T2D was

275 further strengthened by their expression pattern. For $J A G 1$, it is reported to be highly expressed

276 in arteries and in bronchial epithelial cells and lung tissue, with a particularly high level of

277 expression in the gastrointestinal tract tissues, such as small intestine and colon (Supplementary

278 Figs. 4 and 5). For the gene MLXIP, high levels of expression have been consistently noticed in

279 colon tissue as reported in different studies (Supplementary Figs. 6 and 7). Both of these genes

280 demonstrated medium level of expression in certain tissues highly relevant to T2D, including

$281 J A G 1$ in adipose, pancreas, and smooth muscle (Supplementary Figs. 4 and 5), and MLXIP in

282 muscle, pancreas and pancreatic islet cells (Supplementary Figs. 6 and 7).

283 The overall expression pattern of $J A G 1$ is similar to that of the gene Coagulation Factor III $(F 3)$

284 (correlation $>0.7$ ), genetic polymorphisms of which have been shown to be associated with T2D

285 in different ethnicity groups (Palmer et al. 2012; Yamada et al. 2006; Yamaguchi et al. 2007) and

286 the expression of which is significantly higher in monocytes and neutrophils of diabetes and

287 prediabetic subjects (Ichikawa et al. 1998).

288 Consistent with the expression pattern, knockout of $J A G 1$ in a mouse model resulted in defects in

289 endocrine/exocrine glands, homeostasis/metabolism, and the liver/biliary system (Supplementary

290 Fig. 8) (Blake et al. 2017; Finger et al. 2017). MLXIP-deficient mice displayed distinct metabolic 
291 features including increased serum lactate and alanine levels, consumption of fatty acids for

292 energy production during exercise, and increased glycolytic capacity in skeletal muscles. These

293 features are associated with T2D in humans (Crawford et al. 2010; Imamura et al. 2014; Karpe et

294 al. 2011).

295

296 Replication of previously reported T2D loci. Previous genetic and genomic studies of T2D

297 have yielded fruitful results. Based on literature review and a search of the NHGRI-EBI GWAS

298 catalog (Welter et al. 2014), we generated a list of 182 genes which have been reported to be

299 associated with T2D. Among them, 86 have intragenic SNPs or nearby SNPs that are nominally

300 significant in our meta-analysis of Jordan subpopulations (Supplementary Table 4),

301 demonstrating the validity of our study even with a small sample size and support for common

302 genetic basis of T2D in different ethnicities.

303

304 Discussion

305 In this first GWAS of T2D in Jordan subpopulations, we identified a novel genome-wide

306 significant locus at chr20p12.2 close to gene $J A G 1$ and replicated the association in the samples

307 of European ancestry of the WTCCC dataset. JAG1 is expressed in T2D relevant tissues and

308 knockout of $J A G 1$ resulted in T2D related phenotypes in mice. We also found an interesting

309 locus of suggestive significance at $12 \mathrm{q} 24.31$ in the intron of MLXIP. We further showed there is

310 strong eQTL effect of the top associated SNP at this locus with correlation between its genotype 
311 and methylation of MLXIP, suggesting this locus may confer a cis-regulatory effect on MLXIP

312 expression and this effect is at least in part mediated through methylation.

$314 J A G 1$ encodes a ligand for receptor Notch 1, functioning in the Notch signaling pathway which

315 is important for multiple cellular functions, especially during normal development and

316 pathogenesis of cancer (Bray 2016). Accumulative evidence demonstrate a critical role of the

317 Notch signaling pathway in the regulation of metabolism and that perturbations in Notch

318 signaling may lead to the development of obesity and T2D. It has been shown that over

319 activation of Notch signaling results in stimulation of glycogenolysis and gluconeogenesis in the

320 liver, counteracting insulin effects (Bi \& Kuang 2015; Pajvani et al. 2013; Pajvani et al. 2011).

321 Another role of Notch signaling in diabetes mellitus is to increase lipogenesis via mechanistic

322 target of rapamycin complex 1, resulting in the development of hyperglycemia and fatty liver (Bi

323 \& Kuang 2015; Pajvani et al. 2013), dysfunctions associated with T2D. Positive correlation of

324 Notch signaling with insulin resistance and fatty liver has been reported in humans (Valenti et al.

325 2013). Key roles of Notch signaling also include regulation of adipocyte homeostasis and

326 skeletal muscle homeostasis (Bi \& Kuang 2015). One upstream regulator of JAG1, HMGA1 is

327 also involved in the molecular mechanism of T2D (Bianco et al. 2015). It has been reported that

328 the expression of $J A G 1$ is down-regulated upon HMGA1 depletion by siRNA (Pegoraro et al.

329 2013). HMGA1 encodes a non-histone chromatin associated protein, involved in multiple 
330 important cellular functions underlying pathogenesis of T2D, such as insulin production

331 (Arcidiacono et al. 2014), in insulin action (Iiritano et al. 2012).

332

333 MLXIP encodes MondoA which interacts with MLX. Together they activate transcription of

334 genes involved in glucose metabolism (Sloan \& Ayer 2010). Recent studies demonstrate that in

335 addition to regulation of glucose-sensing transcription, MLXIP plays an important role in Myc

336 activation and subsequent metabolic pathway reprogramming (Carroll et al. 2015). It is well

337 known that Myc has important functions in the pathogenesis of diabetes, through both regulating

338 cell cycle entry and maintaining expansion, regeneration and normal function of beta-cells

339 (Tiwari et al. 2016). It has been shown that abnormal activation of Myc resulted in decreased

340 beta-cell differentiation, proliferation and reduced insulin secretion (Cheung et al. 2010). On the

341 other hand, insufficient Myc expression leads to hyperglycemia and beta-cell inactivity (Guo et

342 al. 2013).

344 The pathological events that can lead to the development of T2D are diverse, such as deficiency 345 and malfunction of beta-cells together with insulin resistance in multiple tissues, including liver 346 and adipose tissues (Tiwari et al. 2016). The likely underlying genes for the novel T2D signals

347 that we identified through GWAS are key players of signaling pathways that could lead to the 348 development of T2D. 
350 It is interesting that in our study, we observed a positive correlation between methylation and

351 MLXIP expression that was associated with the rs4758690 SNP. While methylation at promoter

352 sites usually results in gene silencing, methylation at other gene sites often enhances gene

353 expression (Yang et al. 2014) or affects splicing (Jones 2012). The presence of histone

354 modification marks and transcription factor binding in the vicinity of methylation probe

$355 \operatorname{cg} 22729539$ suggests that this region contains cis-regulatory elements that actively regulate

356 transcription. These epigenetic factors, like DNA methylation and histone modification, may

357 interact with each other to influence gene expression in either the same or opposite directions

358 (Banovich et al. 2014; Cedar \& Bergman 2009). DNA methylation could also affect nearby

359 transcription factor binding, such as transcription factor CEBPB, which plays an important role

360 in adipogenesis (Darlington et al. 1998), ER stress and pancreatic $\beta$ cell failure (Matsuda et al.

361 2010). The coordination between a variety of genetic and epigenetic factors may regulate the

362 expression of MLXIP, and further the development of T2D.

364 The two SNPs, rs6134031 and rs4758690 have been reported to be associated with other human

365 traits, though genome-wide significance was not reached in those studies. In the NHGRI-EBI

366 GWAS catalog (Welter et al. 2014), SNP rs6134031 has been reported to be associated with

367 Plasma omega-6 polyunsaturated fatty acid levels (linoleic acid, n-6 PUFAs ) (rs6134031-T,

368 beta $=0.0372, \mathrm{P}$-value $\left.=4 \times 10^{-6}\right)($ Dorajoo et al. 2015). The relationship between $\mathrm{n}-6$ PUFAs and

369 T2D is debatable. Generally, n-6 PUFAs are considered to be proinflammatory and n-3 PUFAs 
370 to be anti-inflammatory. Thus, high dietary intake of n-6 PUFAs and elevated (n-6) to (n-3) ratio

371 are associated with chronic inflammatory diseases including T2D (Patterson et al. 2012;

372 Simopoulos 2016). However, a recent study by Forouhi N.G. et al in a large number of European

373 subjects found that different types of n-6 PAFUs are differentially associated with risk of T2D

374 (Forouhi et al. 2016). Linoleic acid (LA) and eicosadienoic acid (EDA) were inversely

375 associated with T2D $(\mathrm{OR}<1)$, arachidonic acid (AA) was not significantly associated, and $\gamma$ -

376 linolenic acid (GLA), dihomo-GLA, docosatetraenoic acid (DTA), docosapentaenoic acid (n6-

377 DPA) are positively associated (OR $>1)$. Thus the relationship between n-6 PUFAs (and its

378 subtypes) and T2D needs to be further evaluated in more studies. SNP rs4758690 is also

379 associated with height $\left(\mathrm{P}\right.$-value $\left.=2.396 \times 10^{-5}\right)$, however the effect size and direction of effect are

380 not available (Lango Allen et al. 2010). A systematic review and meta-analysis of 18 studies

381 revealed that significant inverse association between height and T2D risk was only observed in

382 women, not men (Janghorbani et al. 2012). Thus the genotype of these 2 SNPs are important for

383 inter-related human traits, suggesting these traits share common molecular underpinnings.

384

385 Our study has started to reveal the similarities and differences of the genetic basis of T2D

386 between Jordan subpopulations and other ethnicities. Despite the small sample size, we were

387 able to replicate almost half of the loci that were reported to be associated with T2D in genetic

388 and genomic studies in other populations. The replication of these associations suggests some

389 common genetic basis underlying the development of T2D among different ethnicities. For 
390 complex traits and diseases, there are many GWAS loci which could not be replicated across

391 different ethnicities, such as the SNP rs7756992 in the CDKAL1 gene which strongly associates

392 with T2D in subjects of European ancestry, but displayed no association in a population of West

393 Africa (Steinthorsdottir et al. 2007). Among the 37 SNPs associated with T2D in European or

394 Asian populations, only 2 were replicated in a Qatari population (O'Beirne et al. 2016). In the

395 Jordan subpopulations examined, we observed a significant association of rs6134031 and T2D,

396 with a very large effect size. In the WTCCC, including only subjects of European ancestry, the

397 LD structure for this region is different and the association of rs6134031 with T2D is less strong.

398 The association at SNP rs4758690 is nominally significant in both Jordan subpopulations,

399 however it is not significant in WTCCC subjects of European ancestry. The identification of

400 these two loci suggested unique genetic determinants for T2D in the Jordan subpopulations. The

401 separate GWAS performed in Chechen and Circassian subpopulations also suggest distinct

402 genetic factors for T2D in each of these two ethnicities. As reviewed by Rosenberg et al

403 (Rosenberg et al. 2010), such ethnic population differences may arise from variations in disease

404 allele frequency, effect direction, effect size, distinct LD patterns, and trait/disease phenotype

405 prevalence. Therefore, it is important to carry out genetic studies in different ethnic groups.

406

407 A major limitation of our study is the small size, which reduces the statistical power to detect a

408 true effect of the genetic variants. The small sample size may lead to p-values of true

409 associations failing to reach stringent significance thresholds, like the genome-wide significance 
410 threshold of $5 \times 10^{-8}$, resulting in false negatives (type II error). Therefore, we also considered

411 other biological evidence when interpreting our results and we were encouraged by the

412 replication of the $J A G 1$ locus and the strong eQTL signal observed for $M L X I P$, due to their

413 strong biological relevance to T2D. As reported and discussed by other studies, true association

414 may not always reach the conventionally corrected conservative threshold of $5 \times 10^{-8}$ for declaring

415 a genome-wide significance (Nishizawa et al. 2014). In our case, future studies with larger

416 sample sizes of Jordan populations are needed to replicate the findings from our study and to

417 further identify other genetic loci.

418

419 Conclusion

420 Taken together, our results from the first GWAS of T2D conducted in two subpopulations in

421 Jordan have identified novel genetic factors underlying T2D; we additionally demonstrate there

422 is common genetic basis among the different ethnicities as well as certain unique genetic factors

423 that underlie T2D in the Jordan subpopulations. Identification of these novel genetic risk factors

424 will offer the potential to gain further insight into the development of T2D and may help with the

425 development of novel treatments precisely for the Jordan populations, which will reduce disease

426 burden and promote health.

427

428 Acknowledgments 
429 We would like to thank the Circassian and Chechen communities for their cooperation in

430 conducting this study.

431

432

\section{References}

434

435

436

437

438

439

440

441

442

443

444

445

446

447

448

449

450

451

452

453

454

455

456

457

458

459

460

461

462

Ajlouni K, Khader YS, Batieha A, Ajlouni H, and El-Khateeb M. 2008. An increase in prevalence of diabetes mellitus in Jordan over 10 years. J Diabetes Complications 22:317-324.

Arcidiacono B, Iiritano S, Chiefari E, Brunetti FS, Gu G, Foti DP, and Brunetti A. 2014. Cooperation between HMGA1, PDX-1, and MafA is Essential for Glucose-Induced Insulin Transcription in Pancreatic Beta Cells. Front Endocrinol (Lausanne) 5:237. 10.3389/fendo.2014.00237

Banovich NE, Lan X, McVicker G, van de Geijn B, Degner JF, Blischak JD, Roux J, Pritchard JK, and Gilad Y. 2014. Methylation QTLs are associated with coordinated changes in transcription factor binding, histone modifications, and gene expression levels. PLoS Genet 10:e1004663. 10.1371/journal.pgen.1004663

Barbujani G, Nasidze IS, and Whitehead GN. 1994a. Genetic diversity in the Caucasus. Hum Biol 66:639-668.

Barbujani G, Whitehead GN, Bertorelle G, and Nasidze IS. 1994b. Testing hypotheses on processes of genetic and linguistic change in the Caucasus. Hum Biol 66:843-864.

Barrett JC, and Cardon LR. 2006. Evaluating coverage of genome-wide association studies. Nat Genet 38:659-662. 10.1038/ng1801

Bhandare R, Schug J, Le Lay J, Fox A, Smirnova O, Liu C, Naji A, and Kaestner KH. 2010. Genome-wide analysis of histone modifications in human pancreatic islets. Genome Res 20:428-433. 10.1101/gr.102038.109

Bi P, and Kuang S. 2015. Notch signaling as a novel regulator of metabolism. Trends Endocrinol Metab 26:248-255. 10.1016/j.tem.2015.02.006

Bianco A, Chiefari E, Nobile CG, Foti D, Pavia M, and Brunetti A. 2015. The Association between HMGA1 rs146052672 Variant and Type 2 Diabetes: A Transethnic MetaAnalysis. PLoS One 10:e0136077. 10.1371/journal.pone.0136077

Blake JA, Eppig JT, Kadin JA, Richardson JE, Smith CL, Bult CJ, and the Mouse Genome Database G. 2017. Mouse Genome Database (MGD)-2017: community knowledge resource for the laboratory mouse. Nucleic Acids Res 45:D723-D729. 10.1093/nar/gkw1040 
463 Bray SJ. 2016. Notch signalling in context. Nat Rev Mol Cell Biol 17:722-735.

464

465

466

467

468

469

470

471

472

473

474

475

476

477

478

479

480

481

482

483

484

485

486

487

488

489

490

491

492

493

494

495

496

497

498

499

500

10.1038/nrm.2016.94

Bulayeva KB. 2006. Overview of genetic-epidemiological studies in ethnically and demographically diverse isolates of Dagestan, Northern Caucasus, Russia. Croat Med J 47:641-648.

Carroll PA, Diolaiti D, McFerrin L, Gu H, Djukovic D, Du J, Cheng PF, Anderson S, Ulrich M, Hurley JB, Raftery D, Ayer DE, and Eisenman RN. 2015. Deregulated Myc requires MondoA/Mlx for metabolic reprogramming and tumorigenesis. Cancer Cell 27:271285. 10.1016/j.ccell.2014.11.024

Cedar H, and Bergman Y. 2009. Linking DNA methylation and histone modification: patterns and paradigms. Nat Rev Genet 10:295-304. 10.1038/nrg2540

Cheung L, Zervou S, Mattsson G, Abouna S, Zhou L, Ifandi V, Pelengaris S, and Khan M. 2010. c-Myc directly induces both impaired insulin secretion and loss of beta-cell mass, independently of hyperglycemia in vivo. Islets 2:37-45. 10.4161/isl.2.1.10196

Crawford SO, Hoogeveen RC, Brancati FL, Astor BC, Ballantyne CM, Schmidt MI, and Young JH. 2010. Association of blood lactate with type 2 diabetes: the Atherosclerosis Risk in Communities Carotid MRI Study. Int J Epidemiol 39:1647-1655. 10.1093/ije/dyq126

Dajani R, Khader YS, Fatahallah R, El-Khateeb M, Shiyab AH, and Hakooz N. 2012. Diabetes mellitus in genetically isolated populations in Jordan: prevalence, awareness, glycemic control, and associated factors. J Diabetes Complications 26:175-180. 10.1016/j.jdiacomp.2012.03.009

Darlington GJ, Ross SE, and MacDougald OA. 1998. The role of C/EBP genes in adipocyte differentiation. J Biol Chem 273:30057-30060.

Delaneau 0, Marchini J, and Zagury JF. 2012. A linear complexity phasing method for thousands of genomes. Nat Methods 9:179-181. 10.1038/nmeth.1785

Delaneau O, Zagury JF, and Marchini J. 2013. Improved whole-chromosome phasing for disease and population genetic studies. Nat Methods 10:5-6. 10.1038/nmeth.2307

Dorajoo R, Sun Y, Han Y, Ke T, Burger A, Chang X, Low HQ, Guan W, Lemaitre RN, Khor CC, Yuan JM, Koh WP, Ong CN, Tai ES, Liu J, van Dam RM, Heng CK, and Friedlander Y. 2015. A genome-wide association study of n-3 and n- 6 plasma fatty acids in a Singaporean Chinese population. Genes Nutr 10:53. 10.1007/s12263-015-0502-2

Du P, Zhang X, Huang CC, Jafari N, Kibbe WA, Hou L, and Lin SM. 2010. Comparison of Betavalue and $M$-value methods for quantifying methylation levels by microarray analysis. BMC Bioinformatics 11:587. 1471-2105-11-587 [pii]

10.1186/1471-2105-11-587

Encode Project Consortium. 2012. An integrated encyclopedia of DNA elements in the human genome. Nature 489:57-74. 10.1038/nature11247 
501 Finger JH, Smith CM, Hayamizu TF, McCright IJ, Xu J, Law M, Shaw DR, Baldarelli RM, Beal

502

503

504

505

506

507

508

509

510

511

512

513

514

515

516

517

518

519

520

521

522

523

524

525

526

527

528

529

530

531

532

533

534

535

536

537

538 JS, Blodgett O, Campbell JW, Corbani LE, Lewis JR, Forthofer KL, Frost PJ, Giannatto SC, Hutchins LN, Miers DB, Motenko H, Stone KR, Eppig JT, Kadin JA, Richardson JE, and Ringwald M. 2017. The mouse Gene Expression Database (GXD): 2017 update. Nucleic Acids Res 45:D730-D736. 10.1093/nar/gkw1073

Forouhi NG, Imamura F, Sharp SJ, Koulman A, Schulze MB, Zheng J, Ye Z, Sluijs I, Guevara M, Huerta JM, Kroger J, Wang LY, Summerhill K, Griffin JL, Feskens EJ, Affret A, Amiano P, Boeing H, Dow C, Fagherazzi G, Franks PW, Gonzalez C, Kaaks R, Key TJ, Khaw KT, Kuhn T, Mortensen LM, Nilsson PM, Overvad K, Pala V, Palli D, Panico S, Quiros JR, Rodriguez-Barranco M, Rolandsson O, Sacerdote C, Scalbert A, Slimani N, Spijkerman AM, Tjonneland A, Tormo MJ, Tumino R, van der AD, van der Schouw YT, Langenberg C, Riboli E, and Wareham NJ. 2016. Association of Plasma Phospholipid n-3 and n-6 Polyunsaturated Fatty Acids with Type 2 Diabetes: The EPIC-InterAct Case-Cohort Study. PLoS Med 13:e1002094. 10.1371/journal.pmed.1002094

Ghassibe-Sabbagh M, Haber M, Salloum AK, Al-Sarraj Y, Akle Y, Hirbli K, Romanos J, Mouzaya F, Gauguier D, Platt DE, El-Shanti H, and Zalloua PA. 2014. T2DM GWAS in the Lebanese population confirms the role of TCF7L2 and CDKAL1 in disease susceptibility. Sci Rep 4:7351. 10.1038/srep07351

Glans F, Elgzyri T, Shaat N, Lindholm E, Apelqvist J, and Groop L. 2008. Immigrants from the Middle-East have a different form of Type 2 diabetes compared with Swedish patients. Diabet Med 25:303-307. 10.1111/j.1464-5491.2007.02366.x

GTEx Consortium. 2015. Human genomics. The Genotype-Tissue Expression (GTEx) pilot analysis: multitissue gene regulation in humans. Science 348:648-660. 10.1126/science.1262110

Guo S, Dai C, Guo M, Taylor B, Harmon JS, Sander M, Robertson RP, Powers AC, and Stein R. 2013. Inactivation of specific beta cell transcription factors in type 2 diabetes. J Clin Invest 123:3305-3316. 10.1172/JCI65390

Hirschhorn JN, and Daly MJ. 2005. Genome-wide association studies for common diseases and complex traits. Nat Rev Genet 6:95-108.

Howie BN, Donnelly P, and Marchini J. 2009. A flexible and accurate genotype imputation method for the next generation of genome-wide association studies. PLoS Genet 5:e1000529. 10.1371/journal.pgen.1000529

Ichikawa K, Yoshinari M, Iwase M, Wakisaka M, Doi Y, Iino K, Yamamoto M, and Fujishima M. 1998. Advanced glycosylation end products induced tissue factor expression in human monocyte-like U937 cells and increased tissue factor expression in monocytes from diabetic patients. Atherosclerosis 136:281-287.

Iiritano S, Chiefari E, Ventura V, Arcidiacono B, Possidente K, Nocera A, Nevolo MT, Fedele M, Greco A, Greco M, Brunetti G, Fusco A, Foti D, and Brunetti A. 2012. The HMGA1- 
539

540

541

542

543

544

545

546

547

548

549

550

551

552

553

554

555

556

557

558

559

560

561

562

563

564

565

566

567

568

569

570

571

572

573

574

575

576

577

IGF-I/IGFBP system: a novel pathway for modulating glucose uptake. Mol Endocrinol 26:1578-1589. 10.1210/me.2011-1379

Imamura M, Chang BH, Kohjima M, Li M, Hwang B, Taegtmeyer H, Harris RA, and Chan L. 2014. MondoA deficiency enhances sprint performance in mice. Biochem J 464:3548. 10.1042/BJ20140530

Imamura M, Takahashi A, Yamauchi T, Hara K, Yasuda K, Grarup N, Zhao W, Wang X, Huerta-Chagoya A, Hu C, Moon S, Long J, Kwak SH, Rasheed A, Saxena R, Ma RC, Okada Y, Iwata M, Hosoe J, Shojima N, Iwasaki M, Fujita H, Suzuki K, Danesh J, Jorgensen T, Jorgensen ME, Witte DR, Brandslund I, Christensen C, Hansen T, Mercader JM, Flannick J, Moreno-Macias H, Burtt NP, Zhang R, Kim YJ, Zheng W, Singh JR, Tam CH, Hirose H, Maegawa H, Ito C, Kaku K, Watada H, Tanaka Y, Tobe K, Kawamori R, Kubo M, Cho YS, Chan JC, Sanghera D, Frossard P, Park KS, Shu XO, Kim BJ, Florez JC, Tusie-Luna T, Jia W, Tai ES, Pedersen O, Saleheen D, Maeda S, and Kadowaki T. 2016. Genome-wide association studies in the Japanese population identify seven novel loci for type 2 diabetes. Nat Commun 7:10531. 10.1038/ncomms10531

Janghorbani M, Momeni F, and Dehghani M. 2012. Hip circumference, height and risk of type 2 diabetes: systematic review and meta-analysis. Obes Rev 13:1172-1181. 10.1111/j.1467-789X.2012.01030.x

Jones PA. 2012. Functions of DNA methylation: islands, start sites, gene bodies and beyond. Nat Rev Genet 13:484-492. 10.1038/nrg3230

Kabakchiev B, and Silverberg MS. 2013. Expression quantitative trait loci analysis identifies associations between genotype and gene expression in human intestine.

Gastroenterology 144:1488-1496, 1496 e1481-1483. 10.1053/j.gastro.2013.03.001

Kailani W. 2002. Chechens in the Middle East: Between Original and Host Cultures. Caspian Studies Program.

Karpe F, Dickmann JR, and Frayn KN. 2011. Fatty acids, obesity, and insulin resistance: time for a reevaluation. Diabetes 60:2441-2449. 10.2337/db11-0425

Lango Allen H, Estrada K, Lettre G, Berndt SI, Weedon MN, Rivadeneira F, Willer CJ, Jackson AU, Vedantam S, Raychaudhuri S, Ferreira T, Wood AR, Weyant RJ, Segre AV, Speliotes EK, Wheeler E, Soranzo N, Park JH, Yang J, Gudbjartsson D, Heard-Costa NL, Randall JC, Qi L, Vernon Smith A, Magi R, Pastinen T, Liang L, Heid IM, Luan J, Thorleifsson G, Winkler TW, Goddard ME, Sin Lo K, Palmer C, Workalemahu T, Aulchenko YS, Johansson A, Zillikens MC, Feitosa MF, Esko T, Johnson T, Ketkar S, Kraft P, Mangino M, Prokopenko I, Absher D, Albrecht E, Ernst F, Glazer NL, Hayward C, Hottenga JJ, Jacobs KB, Knowles JW, Kutalik Z, Monda KL, Polasek O, Preuss M, Rayner NW, Robertson NR, Steinthorsdottir V, Tyrer JP, Voight BF, Wiklund F, Xu J, Zhao JH, Nyholt DR, Pellikka N, Perola M, Perry JR, Surakka I, Tammesoo ML, Altmaier EL, Amin N, Aspelund T, Bhangale T, Boucher G, Chasman 
578

579

580

581

582

583

584

585

586

587

588

589

590

591

592

593

594

595

596

597

598

599

600

601

602

603

604

605

606

607

608

609

610

611

612

613

614

DI, Chen C, Coin L, Cooper MN, Dixon AL, Gibson Q, Grundberg E, Hao K, Juhani Junttila M, Kaplan LM, Kettunen J, Konig IR, Kwan T, Lawrence RW, Levinson DF, Lorentzon M, McKnight B, Morris AP, Muller M, Suh Ngwa J, Purcell S, Rafelt S, Salem RM, Salvi E, Sanna S, Shi J, Sovio U, Thompson JR, Turchin MC, Vandenput L, Verlaan DJ, Vitart V, White CC, Ziegler A, Almgren P, Balmforth AJ, Campbell H, Citterio L, De Grandi A, Dominiczak A, Duan J, Elliott P, Elosua R, Eriksson JG, Freimer NB, Geus EJ, Glorioso N, Haiqing S, Hartikainen AL, Havulinna AS, Hicks AA, Hui J, Igl W, Illig T, Jula A, Kajantie E, Kilpelainen TO, Koiranen M, Kolcic I, Koskinen S, Kovacs P, Laitinen J, Liu J, Lokki ML, Marusic A, Maschio A, Meitinger T, Mulas A, Pare G, Parker AN, Peden JF, Petersmann A, Pichler I, Pietilainen KH, Pouta A, Ridderstrale M, Rotter JI, Sambrook JG, Sanders AR, Schmidt CO, Sinisalo J, Smit JH, Stringham HM, Bragi Walters G, Widen E, Wild SH, Willemsen G, Zagato L, Zgaga L, Zitting P, Alavere H, Farrall M, McArdle WL, Nelis M, Peters MJ, Ripatti S, van Meurs JB, Aben KK, Ardlie KG, Beckmann JS, Beilby JP, Bergman RN, Bergmann S, Collins FS, Cusi D, den Heijer M, Eiriksdottir G, Gejman PV, Hall AS, Hamsten A, Huikuri HV, Iribarren C, Kahonen M, Kaprio J, Kathiresan S, Kiemeney L, Kocher T, Launer LJ, Lehtimaki T, Melander O, Mosley TH, Jr., Musk AW, Nieminen MS, O'Donnell CJ, Ohlsson C, Oostra B, Palmer LJ, Raitakari O, Ridker PM, Rioux JD, Rissanen A, Rivolta C, Schunkert H, Shuldiner AR, Siscovick DS, Stumvoll M, Tonjes A, Tuomilehto J, van Ommen GJ, Viikari J, Heath AC, Martin NG, Montgomery GW, Province MA, Kayser M, Arnold AM, Atwood LD, Boerwinkle E, Chanock SJ, Deloukas P, Gieger C, Gronberg H, Hall P, Hattersley AT, Hengstenberg C, Hoffman W, Lathrop GM, Salomaa V, Schreiber S, Uda M, Waterworth D, Wright AF, Assimes TL, Barroso I, Hofman A, Mohlke KL, Boomsma DI, Caulfield MJ, Cupples LA, Erdmann J, Fox CS, Gudnason V, Gyllensten U, Harris TB, Hayes RB, Jarvelin MR, Mooser V, Munroe PB, Ouwehand WH, Penninx BW, Pramstaller PP, Quertermous T, Rudan I, Samani NJ, Spector TD, Volzke H, Watkins H, Wilson JF, Groop LC, Haritunians T, Hu FB, Kaplan RC, Metspalu A, North KE, Schlessinger D, Wareham NJ, Hunter DJ, O'Connell JR, Strachan DP, Wichmann HE, Borecki IB, van Duijn CM, Schadt EE, Thorsteinsdottir U, Peltonen L, Uitterlinden AG, Visscher PM, Chatterjee N, Loos RJ, Boehnke M, McCarthy MI, Ingelsson E, Lindgren CM, Abecasis GR, Stefansson K, Frayling TM, and Hirschhorn JN. 2010. Hundreds of variants clustered in genomic loci and biological pathways affect human height. Nature 467:832-838. 10.1038/nature09410

Lin SM, Du P, Huber W, and Kibbe WA. 2008. Model-based variance-stabilizing transformation for Illumina microarray data. Nucleic Acids Res 36:e11. gkm1075 [pii] 10.1093/nar/gkm1075 
615 Marchini J, Howie B, Myers S, McVean G, and Donnelly P. 2007. A new multipoint method

616

617

618

619

620

621

622

623

624

625

626

627

628

629

630

631

632

633

634

635

636

637

638

639

640

641

642

643

644

645

646

647

648

649

650

651

652

653 for genome-wide association studies by imputation of genotypes. Nat Genet 39:906913. $10.1038 / \mathrm{ng} 2088$

Matsuda T, Kido Y, Asahara S, Kaisho T, Tanaka T, Hashimoto N, Shigeyama Y, Takeda A, Inoue T, Shibutani Y, Koyanagi M, Hosooka T, Matsumoto M, Inoue H, Uchida T, Koike M, Uchiyama Y, Akira S, and Kasuga M. 2010. Ablation of C/EBPbeta alleviates ER stress and pancreatic beta cell failure through the GRP78 chaperone in mice.J Clin Invest 120:115-126. 10.1172/JCI39721

Mtiraoui N, Turki A, Nemr R, Echtay A, Izzidi I, Al-Zaben GS, Irani-Hakime N, Keleshian SH, Mahjoub T, and Almawi WY. 2012. Contribution of common variants of ENPP1, IGF2BP2, KCNJ11, MLXIPL, PPARgamma, SLC30A8 and TCF7L2 to the risk of type 2 diabetes in Lebanese and Tunisian Arabs. Diabetes Metab 38:444-449. 10.1016/j.diabet.2012.05.002

Nasidze I, Ling EY, Quinque D, Dupanloup I, Cordaux R, Rychkov S, Naumova O, Zhukova O, Sarraf-Zadegan N, Naderi GA, Asgary S, Sardas S, Farhud DD, Sarkisian T, Asadov C, Kerimov A, and Stoneking M. 2004. Mitochondrial DNA and Y-chromosome variation in the caucasus. Ann Hum Genet 68:205-221.

Nasidze I, Risch GM, Robichaux M, Sherry ST, Batzer MA, and Stoneking M. 2001. Alu insertion polymorphisms and the genetic structure of human populations from the Caucasus. Eur J Hum Genet 9:267-272.

Nishizawa D, Fukuda K, Kasai S, Hasegawa J, Aoki Y, Nishi A, Saita N, Koukita Y, Nagashima M, Katoh R, Satoh Y, Tagami M, Higuchi S, Ujike H, Ozaki N, Inada T, Iwata N, Sora I, Iyo M, Kondo N, Won MJ, Naruse N, Uehara-Aoyama K, Itokawa M, Koga M, Arinami T, Kaneko Y, Hayashida M, and Ikeda K. 2014. Genome-wide association study identifies a potent locus associated with human opioid sensitivity. Mol Psychiatry 19:55-62. 10.1038/mp.2012.164

O'Beirne SL, Salit J, Rodriguez-Flores JL, Staudt MR, Abi Khalil C, Fakhro KA, Robay A, Ramstetter MD, Al-Azwani IK, Malek JA, Zirie M, Jayyousi A, Badii R, Al-Nabet AlMarri A, Chiuchiolo MJ, Al-Shakaki A, Chidiac O, Gharbiah M, Bener A, Stadler D, Hackett NR, Mezey JG, and Crystal RG. 2016. Type 2 Diabetes Risk Allele Loci in the Qatari Population. PLoS One 11:e0156834. 10.1371/journal.pone.0156834

Pajvani UB, Qiang L, Kangsamaksin T, Kitajewski J, Ginsberg HN, and Accili D. 2013. Inhibition of Notch uncouples Akt activation from hepatic lipid accumulation by decreasing mTorc1 stability. Nat Med 19:1054-1060. 10.1038/nm.3259

Pajvani UB, Shawber CJ, Samuel VT, Birkenfeld AL, Shulman GI, Kitajewski J, and Accili D. 2011. Inhibition of Notch signaling ameliorates insulin resistance in a Fox01dependent manner. Nat Med 17:961-967. 10.1038/nm.2378

Palmer ND, McDonough CW, Hicks PJ, Roh BH, Wing MR, An SS, Hester JM, Cooke JN, Bostrom MA, Rudock ME, Talbert ME, Lewis JP, Consortium D, Investigators M, 
654

655

656

657

658

659

660

661

662

663

664

665

666

667

668

669

670

671

672

673

674

675

676

677

678

679

680

681

682

683

684

685

686

687

688

689

690

691

692

Ferrara A, Lu L, Ziegler JT, Sale MM, Divers J, Shriner D, Adeyemo A, Rotimi CN, Ng MC, Langefeld CD, Freedman BI, Bowden DW, Voight BF, Scott LJ, Steinthorsdottir V, Morris AP, Dina C, Welch RP, Zeggini E, Huth C, Aulchenko YS, Thorleifsson G, McCulloch LJ, Ferreira T, Grallert H, Amin N, Wu G, Willer CJ, Raychaudhuri S, McCarroll SA, Langenberg C, Hofmann OM, Dupuis J, Qi L, Segre AV, van Hoek M, Navarro P, Ardlie K, Balkau B, Benediktsson R, Bennett AJ, Blagieva R, Boerwinkle E, Bonnycastle LL, Bostrom KB, Bravenboer B, Bumpstead S, Burtt NP, Charpentier G, Chines PS, Cornelis M, Couper DJ, Crawford G, Doney AS, Elliott KS, Elliott AL, Erdos MR, Fox CS, Franklin CS, Ganser M, Gieger C, Grarup N, Green T, Griffin S, Groves CJ, Guiducci C, Hadjadj S, Hassanali N, Herder C, Isomaa B, Jackson AU, Johnson PR, Jorgensen T, Kao WH, Klopp N, Kong A, Kraft P, Kuusisto J, Lauritzen T, Li M, Lieverse A, Lindgren CM, Lyssenko V, Marre M, Meitinger T, Midthjell K, Morken MA, Narisu N, Nilsson P, Owen KR, Payne F, Perry JR, Petersen AK, Platou C, Proenca C, Prokopenko I, Rathmann W, Rayner NW, Robertson NR, Rocheleau G, Roden M, Sampson MJ, Saxena R, Shields BM, Shrader P, Sigurdsson G, Sparso T, Strassburger K, Stringham HM, Sun Q, Swift AJ, Thorand B, Tichet J, Tuomi T, van Dam RM, van Haeften TW, van Herpt T, van Vliet-Ostaptchouk JV, Walters GB, Weedon MN, Wijmenga C, Witteman J, Bergman RN, Cauchi S, Collins FS, Gloyn AL, Gyllensten U, Hansen T, Hide WA, Hitman GA, Hofman A, Hunter DJ, Hveem K, Laakso M, Mohlke KL, Morris AD, Palmer CN, Pramstaller PP, Rudan I, Sijbrands E, Stein LD, Tuomilehto J, Uitterlinden A, Walker M, Wareham NJ, Watanabe RM, Abecasis GR, Boehm BO, Campbell H, Daly MJ, Hattersley AT, Hu FB, Meigs JB, Pankow JS, Pedersen O, Wichmann HE, Barroso I, Florez JC, Frayling TM, Groop L, Sladek R, Thorsteinsdottir U, Wilson JF, Illig T, Froguel P, van Duijn CM, Stefansson K, Altshuler D, Boehnke M, McCarthy MI, Soranzo N, Wheeler E, Glazer NL, Bouatia-Naji N, Magi R, Randall J, Johnson T, Elliott P, Rybin D, Henneman P, Dehghan A, Hottenga JJ, Song K, Goel A, Egan JM, Lajunen T, Doney A, Kanoni S, Cavalcanti-Proenca C, Kumari M, Timpson NJ, Zabena C, Ingelsson E, An P, O'Connell J, Luan J, Elliott A, McCarroll SA, Roccasecca RM, Pattou F, Sethupathy P, Ariyurek Y, Barter P, Beilby JP, Ben-Shlomo Y, Bergmann S, Bochud M, Bonnefond A, Borch-Johnsen K, Bottcher Y, Brunner E, Bumpstead SJ, Chen YD, Chines P, Clarke R, Coin LJ, Cooper MN, Crisponi L, Day IN, de Geus EJ, Delplanque J, Fedson AC, Fischer-Rosinsky A, Forouhi NG, Frants R, Franzosi MG, Galan P, Goodarzi MO, Graessler J, Grundy S, Gwilliam R, Hallmans G, Hammond N, Han X, Hartikainen AL, Hayward C, Heath SC, Hercberg S, Hicks AA, Hillman DR, Hingorani AD, Hui J, Hung J, Jula A, Kaakinen M, Kaprio J, Kesaniemi YA, Kivimaki M, Knight B, Koskinen S, Kovacs P, Kyvik KO, Lathrop GM, Lawlor DA, Le Bacquer O, Lecoeur C, Li Y, Mahley R, Mangino M, Manning AK, Martinez-Larrad MT, McAteer JB, McPherson R, Meisinger C, Melzer D, Meyre D, Mitchell BD, Mukherjee S, Naitza S, Neville MJ, Oostra BA, Orru M, Pakyz R, Paolisso 
693

694

695

696

697

698

699

700

701

702

703

704

705

706

707

708

709

710

711

712

713

714

715

716

717

718

719

720

721

722

723

724

725

726

727

728

729

730

731

G, Pattaro C, Pearson D, Peden JF, Pedersen NL, Perola M, Pfeiffer AF, Pichler I, Polasek O, Posthuma D, Potter SC, Pouta A, Province MA, Psaty BM, Rayner NW, Rice K, Ripatti S, Rivadeneira F, Rolandsson O, Sandbaek A, Sandhu M, Sanna S, Sayer AA, Scheet P, Seedorf U, Sharp SJ, Shields B, Sijbrands EJ, Silveira A, Simpson L, Singleton A, Smith NL, Sovio U, Swift A, Syddall H, Syvanen AC, Tanaka T, Tonjes A, Uitterlinden AG, van Dijk KW, Varma D, Visvikis-Siest S, Vitart V, Vogelzangs $N$, Waeber G, Wagner PJ, Walley A, Ward KL, Watkins H, Wild SH, Willemsen G, Witteman JC, Yarnell JW, Zelenika D, Zethelius B, Zhai G, Zhao JH, Zillikens MC, Borecki IB, Loos RJ, Meneton P, Magnusson PK, Nathan DM, Williams GH, Silander K, Salomaa V, Smith GD, Bornstein SR, Schwarz P, Spranger J, Karpe F, Shuldiner AR, Cooper C, Dedoussis GV, Serrano-Rios M, Lind L, Palmer LJ, Franks PW, Ebrahim S, Marmot M, Kao WH, Pramstaller PP, Wright AF, Stumvoll M, Hamsten A, Buchanan TA, Valle TT, Rotter JI, Siscovick DS, Penninx BW, Boomsma DI, Deloukas P, Spector TD, Ferrucci L, Cao A, Scuteri A, Schlessinger D, Uda M, Ruokonen A, Jarvelin MR, Waterworth DM, Vollenweider P, Peltonen L, Mooser V, and Sladek R. 2012. A genome-wide association search for type 2 diabetes genes in African Americans. PLoS One 7:e29202. 10.1371/journal.pone.0029202

Parker SC, Stitzel ML, Taylor DL, Orozco JM, Erdos MR, Akiyama JA, van Bueren KL, Chines PS, Narisu N, Program NCS, Black BL, Visel A, Pennacchio LA, Collins FS, National Institutes of Health Intramural Sequencing Center Comparative Sequencing Program A, and Authors NCSP. 2013. Chromatin stretch enhancer states drive cellspecific gene regulation and harbor human disease risk variants. Proc Natl Acad Sci U S A 110:17921-17926. 10.1073/pnas.1317023110

Pasquali L, Gaulton KJ, Rodriguez-Segui SA, Mularoni L, Miguel-Escalada I, Akerman I, Tena JJ, Moran I, Gomez-Marin C, van de Bunt M, Ponsa-Cobas J, Castro N, Nammo T, Cebola I, Garcia-Hurtado J, Maestro MA, Pattou F, Piemonti L, Berney T, Gloyn AL, Ravassard P, Gomez-Skarmeta JL, Muller F, McCarthy MI, and Ferrer J. 2014. Pancreatic islet enhancer clusters enriched in type 2 diabetes risk-associated variants. Nat Genet 46:136-143. 10.1038/ng.2870

Patterson E, Wall R, Fitzgerald GF, Ross RP, and Stanton C. 2012. Health implications of high dietary omega-6 polyunsaturated Fatty acids. J Nutr Metab 2012:539426. 10.1155/2012/539426

Pe'er I, de Bakker PI, Maller J, Yelensky R, Altshuler D, and Daly MJ. 2006. Evaluating and improving power in whole-genome association studies using fixed marker sets. Nat Genet 38:663-667. 10.1038/ng1816

Pegoraro S, Ros G, Piazza S, Sommaggio R, Ciani Y, Rosato A, Sgarra R, Del Sal G, and Manfioletti G. 2013. HMGA1 promotes metastatic processes in basal-like breast cancer regulating EMT and stemness. Oncotarget 4:1293-1308.

10.18632/oncotarget.1136

Peer) reviewing PDF | (2017:03:16832:1:1:ACCEPTED 27 Jun 2017) 
732 Price AL, Patterson NJ, Plenge RM, Weinblatt ME, Shadick NA, and Reich D. 2006. Principal

733

734

735

736

737

738

739

740

741

742

743

744

745

746

747

748

749

750

751

752

753

754

755

756

757

758

759

760

761

762

763

764

765

766

767

768

769

770 components analysis corrects for stratification in genome-wide association studies. Nat Genet 38:904-909. 10.1038/ng1847

Pruim RJ, Welch RP, Sanna S, Teslovich TM, Chines PS, Gliedt TP, Boehnke M, Abecasis GR, and Willer CJ. 2010. LocusZoom: regional visualization of genome-wide association scan results. Bioinformatics 26:2336-2337. 10.1093/bioinformatics/btq419

Purcell S, Neale B, Todd-Brown K, Thomas L, Ferreira MA, Bender D, Maller J, Sklar P, de Bakker PI, Daly MJ, and Sham PC. 2007. PLINK: a tool set for whole-genome association and population-based linkage analyses. Am J Hum Genet 81:559-575. $10.1086 / 519795$

Roadmap Epigenomics C, Kundaje A, Meuleman W, Ernst J, Bilenky M, Yen A, HeraviMoussavi A, Kheradpour P, Zhang Z, Wang J, Ziller MJ, Amin V, Whitaker JW, Schultz MD, Ward LD, Sarkar A, Quon G, Sandstrom RS, Eaton ML, Wu YC, Pfenning AR, Wang X, Claussnitzer M, Liu Y, Coarfa C, Harris RA, Shoresh N, Epstein CB, Gjoneska E, Leung D, Xie W, Hawkins RD, Lister R, Hong C, Gascard P, Mungall AJ, Moore R, Chuah E, Tam A, Canfield TK, Hansen RS, Kaul R, Sabo PJ, Bansal MS, Carles A, Dixon JR, Farh KH, Feizi S, Karlic R, Kim AR, Kulkarni A, Li D, Lowdon R, Elliott G, Mercer TR, Neph SJ, Onuchic V, Polak P, Rajagopal N, Ray P, Sallari RC, Siebenthall KT, Sinnott-Armstrong NA, Stevens M, Thurman RE, Wu J, Zhang B, Zhou X, Beaudet AE, Boyer LA, De Jager PL, Farnham PJ, Fisher SJ, Haussler D, Jones SJ, Li W, Marra MA, McManus MT, Sunyaev S, Thomson JA, Tlsty TD, Tsai LH, Wang W, Waterland RA, Zhang MQ, Chadwick LH, Bernstein BE, Costello JF, Ecker JR, Hirst M, Meissner A, Milosavljevic A, Ren B, Stamatoyannopoulos JA, Wang T, and Kellis M. 2015. Integrative analysis of 111 reference human epigenomes. Nature 518:317-330. 10.1038 /nature14248

Rosenberg NA, Huang L, Jewett EM, Szpiech ZA, Jankovic I, and Boehnke M. 2010. Genomewide association studies in diverse populations. Nat Rev Genet 11:356-366. $10.1038 / \mathrm{nrg} 2760$

Simopoulos AP. 2016. An Increase in the Omega-6/0mega-3 Fatty Acid Ratio Increases the Risk for Obesity. Nutrients 8:128. 10.3390/nu8030128

Sloan EJ, and Ayer DE. 2010. Myc, mondo, and metabolism. Genes Cancer 1:587-596. $10.1177 / 1947601910377489$

Steinthorsdottir V, Thorleifsson G, Reynisdottir I, Benediktsson R, Jonsdottir T, Walters GB, Styrkarsdottir U, Gretarsdottir S, Emilsson V, Ghosh S, Baker A, Snorradottir S, Bjarnason H, Ng MC, Hansen T, Bagger Y, Wilensky RL, Reilly MP, Adeyemo A, Chen Y, Zhou J, Gudnason V, Chen G, Huang H, Lashley K, Doumatey A, So WY, Ma RC, Andersen G, Borch-Johnsen K, Jorgensen T, van Vliet-Ostaptchouk JV, Hofker MH, Wijmenga C, Christiansen C, Rader DJ, Rotimi C, Gurney M, Chan JC, Pedersen O, Sigurdsson G, Gulcher JR, Thorsteinsdottir U, Kong A, and Stefansson K. 2007. A 
771

772

773

774

775

776

777

778

779

780

781

782

783

784

785

786

787

788

789

790

791

792

793

794

795

796

variant in CDKAL1 influences insulin response and risk of type 2 diabetes. Nat Genet 39:770-775. 10.1038/ng2043

Tiwari S, Roel C, Tanwir M, Wills R, Perianayagam N, Wang P, and Fiaschi-Taesch NM. 2016. Definition of a Skp2-c-Myc Pathway to Expand Human Beta-cells. Sci Rep 6:28461. 10.1038/srep28461

Valenti L, Mendoza RM, Rametta R, Maggioni M, Kitajewski C, Shawber CJ, and Pajvani UB. 2013. Hepatic notch signaling correlates with insulin resistance and nonalcoholic fatty liver disease. Diabetes 62:4052-4062. 10.2337/db13-0769

Wellcome Trust Case Control C. 2007. Genome-wide association study of 14,000 cases of seven common diseases and 3,000 shared controls. Nature 447:661-678. 10.1038/nature05911

Welter D, MacArthur J, Morales J, Burdett T, Hall P, Junkins H, Klemm A, Flicek P, Manolio T, Hindorff L, and Parkinson H. 2014. The NHGRI GWAS Catalog, a curated resource of SNP-trait associations. Nucleic Acids Res 42:D1001-1006. 10.1093/nar/gkt1229

Wild S, Roglic G, Green A, Sicree R, and King H. 2004. Global prevalence of diabetes: estimates for the year 2000 and projections for 2030. Diabetes Care 27:1047-1053.

Yamada Y, Matsuo H, Segawa T, Watanabe S, Kato K, Kameyama T, Yokoi K, Ichihara S, Metoki N, Yoshida H, Satoh K, and Nozawa Y. 2006. Assessment of genetic factors for type 2 diabetes mellitus. Int J Mol Med 18:299-308.

Yamaguchi S, Yamada Y, Matsuo H, Segawa T, Watanabe S, Kato K, Yokoi K, Ichihara S, Metoki N, Yoshida H, Satoh K, and Nozawa Y. 2007. Gender differences in the association of gene polymorphisms with type 2 diabetes mellitus. Int J Mol Med 19:631-637.

Yang X, Han H, De Carvalho DD, Lay FD, Jones PA, and Liang G. 2014. Gene body methylation can alter gene expression and is a therapeutic target in cancer. Cancer Cell 26:577-590. 10.1016/j.ccr.2014.07.028 


\section{Tables:}

799 Table 1. The number of samples after quality control filtering.

\begin{tabular}{|l|lllll|}
\hline \multirow{2}{*}{ Ethnicity } & Cases & \multicolumn{3}{c|}{ Controls } & Total \\
\cline { 2 - 6 } & $\mathbf{N}$ & male \% & N & male \% & N \\
\hline Chechen & 34 & $47 \%$ & 109 & $40 \%$ & 143 \\
Circassian & 33 & $39 \%$ & 105 & $45 \%$ & 138 \\
Total & 67 & & 214 & & 281 \\
\hline
\end{tabular}

800

$\mathrm{N}=$ Number

801

802 Table 2. Top associations $\left(\mathrm{P}<5 \times 10^{-5}\right)$ found in meta-analysis of Circassian and Chechen 803 subpopulations.

\begin{tabular}{|c|c|c|c|c|c|c|c|c|}
\hline SNP & Chr & Pos (hg19) & Gene & $\mathrm{A} 1 / \mathrm{A} 2$ & Ethnicity & $\begin{array}{l}\text { MAF } \\
\text { cases/controls }\end{array}$ & $\begin{array}{l}\text { OR }(95 \% \\
\mathrm{CI})\end{array}$ & P-value \\
\hline \multirow[t]{4}{*}{ rs6134031 } & 20 & 10752610 & $J A G 1$ & $\mathrm{~T} / \mathrm{C}$ & Circassian & $0.50 / 0.25$ & $\begin{array}{l}9.48 \\
(3,09,29.07)\end{array}$ & $8.36 \times 10^{-5}$ \\
\hline & & & & & Chechen & $0.51 / 0.23$ & $\begin{array}{l}9.84 \\
(3.33,29.02)\end{array}$ & $3.45 \times 10^{-5}$ \\
\hline & & & & & Meta & & 9.66 & $1.12 \times 10^{-8}$ \\
\hline & & & & & European & $0.28 / 0.26$ & $\begin{array}{l}1.12 \\
(1.03,1.23)\end{array}$ & 0.012 \\
\hline \multirow[t]{4}{*}{ rs4758690 } & 12 & 122610909 & $M L X I P$ & $\mathrm{G} / \mathrm{A}$ & Circassian & $0.59 / 0.41$ & $\begin{array}{l}2.41 \\
(1.19,4.91)\end{array}$ & 0.015 \\
\hline & & & & & Chechen & $0.60 / 0.38$ & $\begin{array}{l}3.89 \\
(1.78,8.47)\end{array}$ & $6.36 \times 10^{-4}$ \\
\hline & & & & & Meta & & 3.00 & $4.20 \times 10^{-5}$ \\
\hline & & & & & European & $0.53 / 0.52$ & $\begin{array}{l}1.01 \\
(0.93,1.09)\end{array}$ & 0.61 \\
\hline
\end{tabular}

804 SNP - single nucleotide polymorphism; Chr - chromosome; Pos - Position; A1 - minor allele; A2 - major allele; MAF - minor allele frequency;

805 OR - odds ratio; CI - confidence interval

806

807 
808

809

810 Figures :

811

812 Figure 1: The regional association plots for the top associated loci. (a) chr20p12.2 locus in

813 Circassian population; (b) chr20p12.2 locus in Chechen population; (c) chr12q24.31 in Chechen

814 population. The top associated SNP at each locus is shown in purple and the LD between the

815 remaining SNPs and the index SNP are indicated by their colors. The $\mathrm{r}^{2}$ values were calculated

816 from the each population using software PLINK (Purcell et al. 2007). The recombination rates

817 are shown by the light blue lines and the genomic positions are on human genome build hg19.

818 The plots were made using software LocusZoom (Pruim et al. 2010).

a

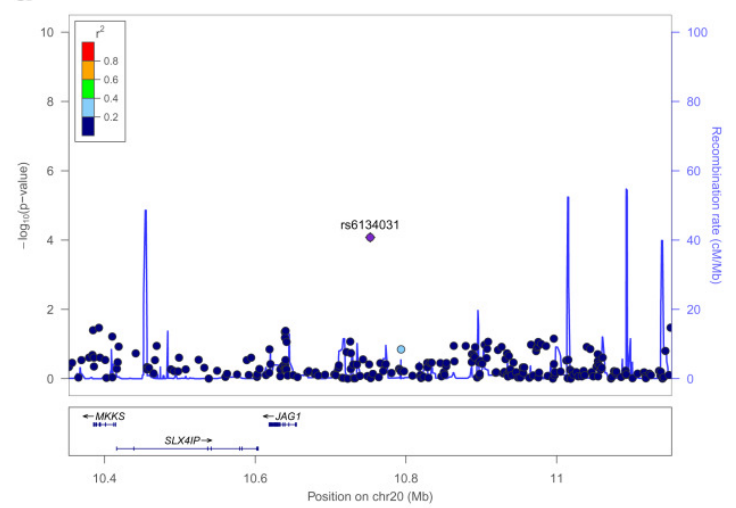

C

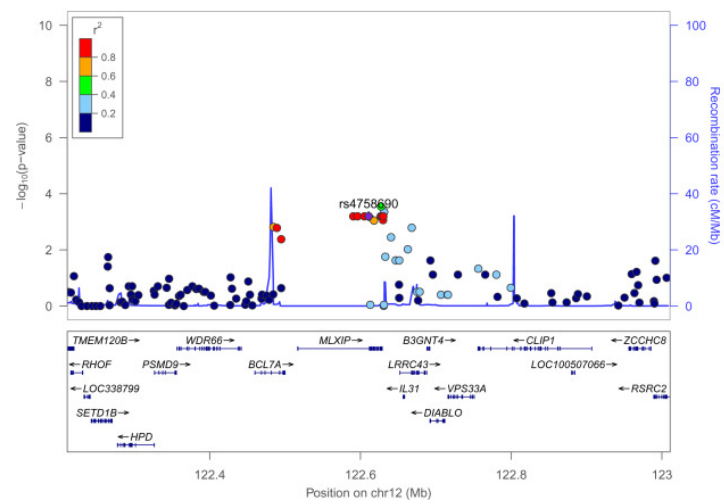

b

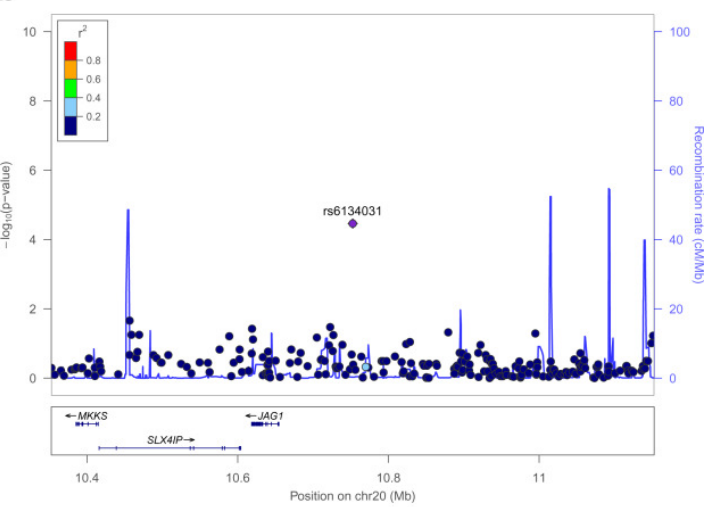

819

820

821 
824 Figure 2: Box plots showing the association between SNP rs4758690 genotype and gene MLXIP 825 expression level. (a) in tissue transverse colon, beta $=0.46, \mathrm{P}=1.10 \times 10^{-14}$; (b) in tissue small 826 intestine, beta $=0.50, \mathrm{P}=4.20 \times 10^{-7}$. The in silico analyses were conducted at GTEx Protal (GTEx 827 Consortium 2015). The sample groups of different rs4758690 genotype were indicated on the X828 axis; and the relative expression level of MLXIP is shown on the Y-axis. The median value of 829 MLXIP expression level in each genotype group is represented by the dark black horizontal line 830 in the box plot. In the both figures, the reference allele is $\mathrm{G}$ and the alternative allele is A.

a

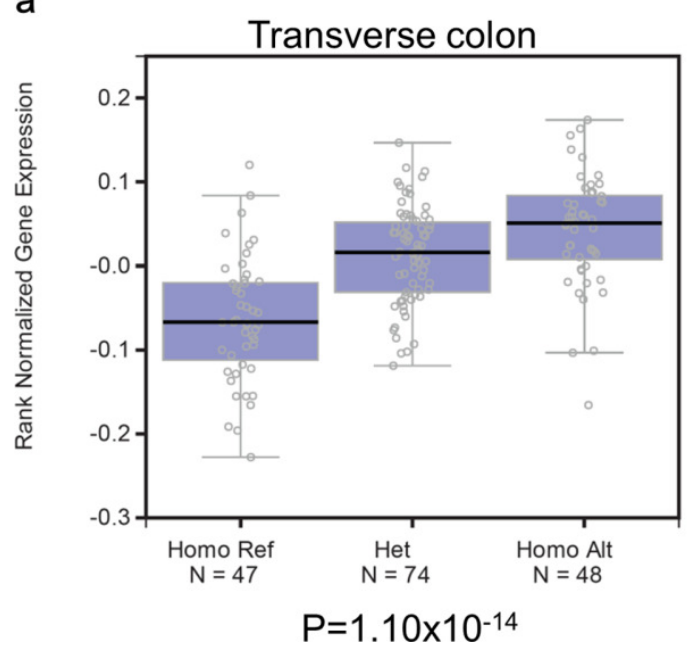

b

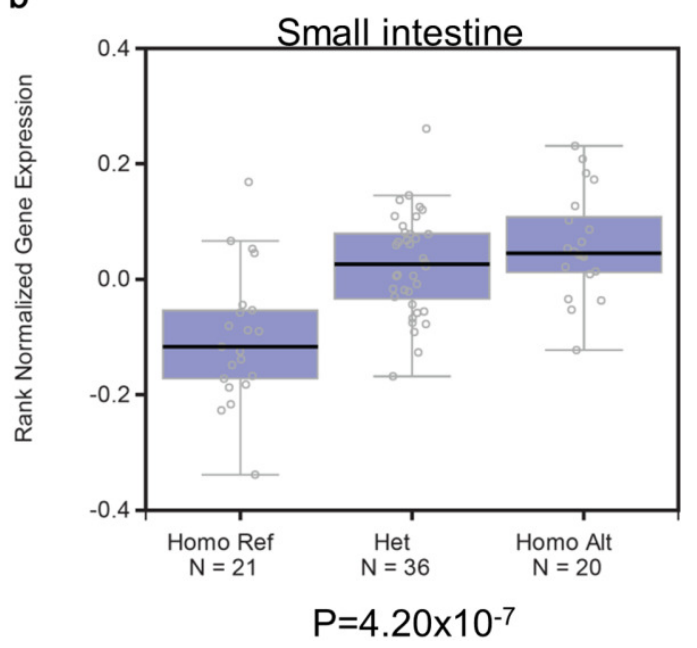

831

832

833

834

835

836

837

838

839

840 
841

842

843

844 Figure 3. The association between SNP rs4758690 genotype and methylation status in gene

845 MLXIP. M-values for methylation probe cg22729539 are plotted against the additive genotype at

846 SNP rs4758690. Dark horizontal lines in the boxplots represent the median of the group, the

847 boxes show the $25 \%-75 \%$ quantiles, and the whiskers of the boxplot extend beyond those

848 quartiles to 1.5 times the interquartile range (IQR). Open circles indicate data outside the 1.5

849 IQR. Red diamonds indicate the means of each group, and the red text is the mean \pm standard

850 deviation of each group. The number of individuals with each additive genotype of minor allele

$851 \mathrm{G}$ is shown below the $\mathrm{X}$-axis.

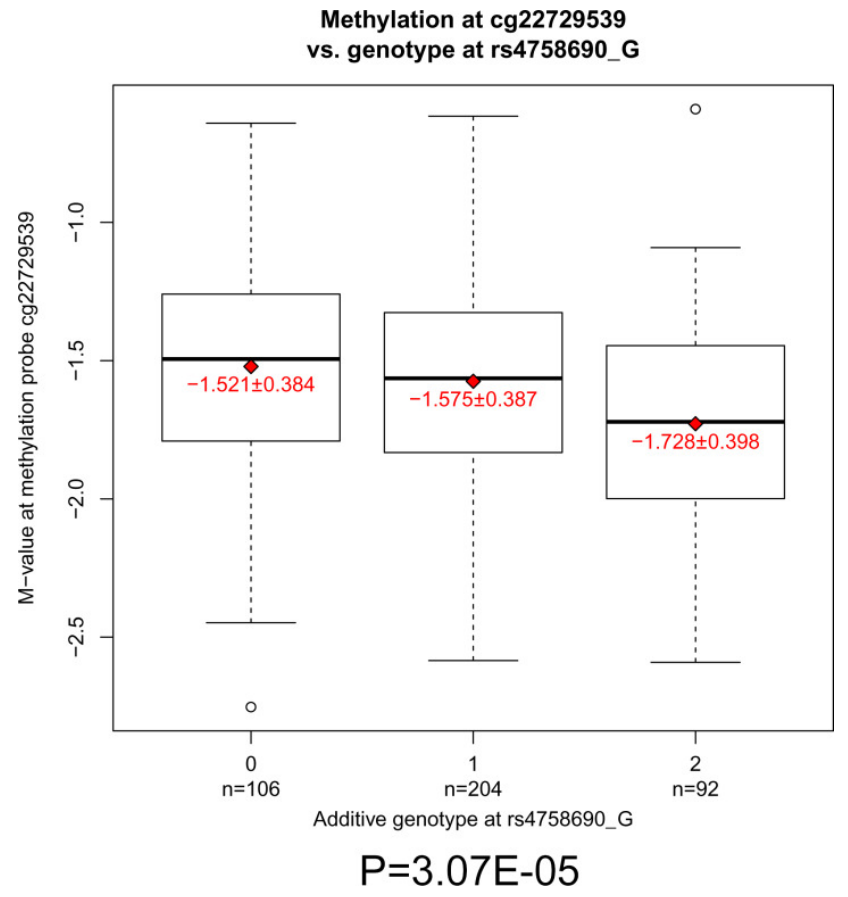

853 